\section{LANGUAGE LEARNING STRATEGIES USED BY THAI AND VIETNAMESE UNIVERSITY STUDENTS}

\section{Attapol Khamkhien ${ }^{1}$}

\begin{abstract}
Based on several standardized tests, previous studies show that Vietnamese youths have higher proficiency in English than Thai youths in spite of the latter's social advantages. An explanation for the discrepancy is probably that the two groups use different strategies in learning English. This study reports the results of an investigation into language learning strategies commonly used by Thai and Vietnamese university students, using the Strategy Inventory for Language Learning (SILL) developed by Oxford (1990) and semi-structured interviews. A comparison of the patterns of language learning strategies used by the two student groups revealed some resemblances and differences, illustrating what teachers and students should know to successfully teach and learn English, respectively. It is hoped that the findings of this study will be of particular benefit to educational planners, methodologists, and classroom teachers; they will not only help them better understand the strategies used by Thai students in learning English, but also facilitate the process of improving English education in Thailand.
\end{abstract}

\footnotetext{
${ }^{1}$ Lecturer, Department of Liberal Arts, Faculty of Liberal Arts and Science, Kasetsart University
}

\section{Introduction}

English has acquired the status of an international language. As a result of globalization, it is used as a lingua franca in numerous aspects of life including business and international communication. Consequently, learning English is needed, and the demand for speakers with high proficiency in English is increasing in many countries, including Thailand.

Thailand recognizes the importance of English and has pursued a policy of learning English for international advancement. Despite the fact that Thai students study English for many years in schools before entering university, they only have limited success in learning English (Chulalongkorn University Academic Service Center 2000). Several key educators have made a great effort to change the current English curriculum from focusing on a traditional, grammar-based approach to a functionalcommunicative approach. However, the majority of these initiatives have failed to achieve their goals. Foley (2005) pointed out that a number of factors are likely to have contributed to this failure; namely, a shortage of teaching materials for primary school students, a shortage of well-trained teachers of English, and a lack of opportunities for exposure to authentic English in the classroom.

A large number research studies (e.g. Bunnag 2005; Prapphal and Opanonamata 2002) have been conducted with a focus on the English proficiency of Thai students. Such studies revealed that, as measured by several standardized tests e.g., the Test of English as a Foreign Language (TOEFL), the Test of English for International Communication (TOEIC), Thai students showed poorer English skills than those in other countries 
in Southeast Asia, including Burma, Indonesia, Malaysia, Singapore, the Philippines, and Vietnam. Indeed, in Southeast Asia, Thais were the secondworst in English language skills. Although more studies are needed to verify Bunnag and Prapphal and Opanonamata's conclusions because the test takers may be diverse and heterogeneous, their studies are intriguing as they reveal how unsatisfactory Thai learners' proficiency in English is. The studies also call for more in-depth research to investigate, for example, how English should be taught, and how Thai students learn English. In other words, in order for Thais to successfully participate in the international community, English education needs to be substantially improved.

Providing a general description of the limited success of Thailand's English education, Yunibandhu (2004) investigated the English proficiency of Thai students making the transition from the Thai school system to the international school system. Her study astutely pointed out that Thai students learning at international schools faced linguistic problems including poor English reading and writing skills. Also, these students possessed a low degree of grammatical accuracy in speaking, and encountered difficulty in identifying information when listening. Therefore, it can be concluded that, not only most Thai students studying in schools, but those entering and studying at international schools, who are generally expected that they should process above average of English skills, have a relatively low degree of their English performance. Overall, the results of previous studies focusing on Thai learners' English proficiency indicated that Thai learners had low proficiency in English skills and thus failed to achieve the standards required.

\section{Why Vietnamese Students?}

Among the nine ASEAN member countries, as far as English language education is concerned, Vietnam deserves our attention for several reasons. Historically, Vietnam was colonized by the Chinese for a very long time, and subsequently by the French, while Thailand is the only country in Southeast Asia never colonized by a European power. Consequently, Vietnamese picked the Roman alphabet from the French to be their alphabet unlike Thailand which has its own alphabet. Furthermore, with respect to the political and economic situation, Brogan and Thai Ha (1999) illustrated that Vietnam has changed a great deal during the past two decades due to the Vietnamese government's Doi Moi policy. This economic open-door policy has resulted in an increase in Vietnam's political, diplomatic and economic relationships with other countries. These changes have demanded a greater number of speakers proficient in English. Concerning the importance of English as an essential tool in international trade and business in Southeast Asia, both Thailand and Vietnam want to be stronger members of the global economy. English is needed not just as a subject to be learned in the classroom but also as a medium for social and practical use.

More interestingly, regarding teaching and learning English, in 1992, Angwattanagul (1992) reported that, in Thailand, English was first taught as a foreign language in schools by British missionaries in 1845, but the Thai government has continued reforming the education system for a long time to improve Thai students' English proficiency. In Vietnam, according to Thinh (1999), teaching and learning English is very limited. English was first taught twenty 
years ago. The importance of English in Vietnam was recognized when Vietnam adopted its Doi Moi policy in 1986. Since then, English has been taught as a foreign language to students from Grade 6 through secondary school. Although there are differences in the history and development of teaching and learning English in these two countries, it is very interesting that English education in Vietnam has rapidly improved as demonstrated by the fact that Vietnamese students scored higher in several standardized tests when compared with Thai students' scores.

\section{Language Learning Strategies}

For two decades, researchers and practitioners have attempted to define and explain language learning strategies. In fact, experts share some common ground in their definitions. For example, Oxford (1990) defines language learning strategies as follows:

...steps taken by students to enhance their own learning. Strategies are especially important for language learning because they are tools for active, self-directed involvement, which is essential for developing communicative competence. They are specific actions taken by the learner to make learning easier, faster, more enjoyable, more selfdirected, more effective, and more transferable to new situations.

(Oxford 1990: 8)

Oxford (1990: 37) also categorizes language learning strategies into two domains: Direct Strategies and Indirect Strategies. "Direct Strategies mean language learning strategies that directly involve the target language. All direct strategies require mental processing of the language." The three groups of Direct
Strategies are as follows:

1. Memory strategies - techniques specifically tailored to help the learner store new information in their memory and retrieve it later on, e.g., placing new words in context, using keywords and representing sounds in memory, etc.

2. Cognitive strategies - skills that allow students to better comprehend and produce language in different ways, e.g., note-taking, repetition, summarizing text, etc.

3. Compensation strategies - behaviours used to compensate and help them to employ the language, e.g., guessing while listening or reading, or using synonyms or paraphrasing while speaking or writing.

As opposed to Direct Strategies, "Indirect Strategies provide indirect support for language learning through focusing, planning, evaluating, seeking opportunities, controlling anxiety, increasing cooperation and empathy, and other means" (Oxford 1990: 151). The three sets of Indirect Strategies are as follows.

4. Metacognitive strategies - behaviours used for arranging, planning and evaluating one's learning, e.g., overviewing and linking with already known material.

5. Affective strategies - techniques which regulate emotional behaviours and motivation, e.g., using relaxation techniques, singing songs in a target language to lower one's anxiety, etc.

6. Social strategies - actions allowing better learner interaction with other people in the language learning process, e.g., asking questions, cooperating with peers, and developing empathy towards target language speaking people, etc. 
Figure 1: Oxford's Language Learning Strategies Taxonomy (1990)

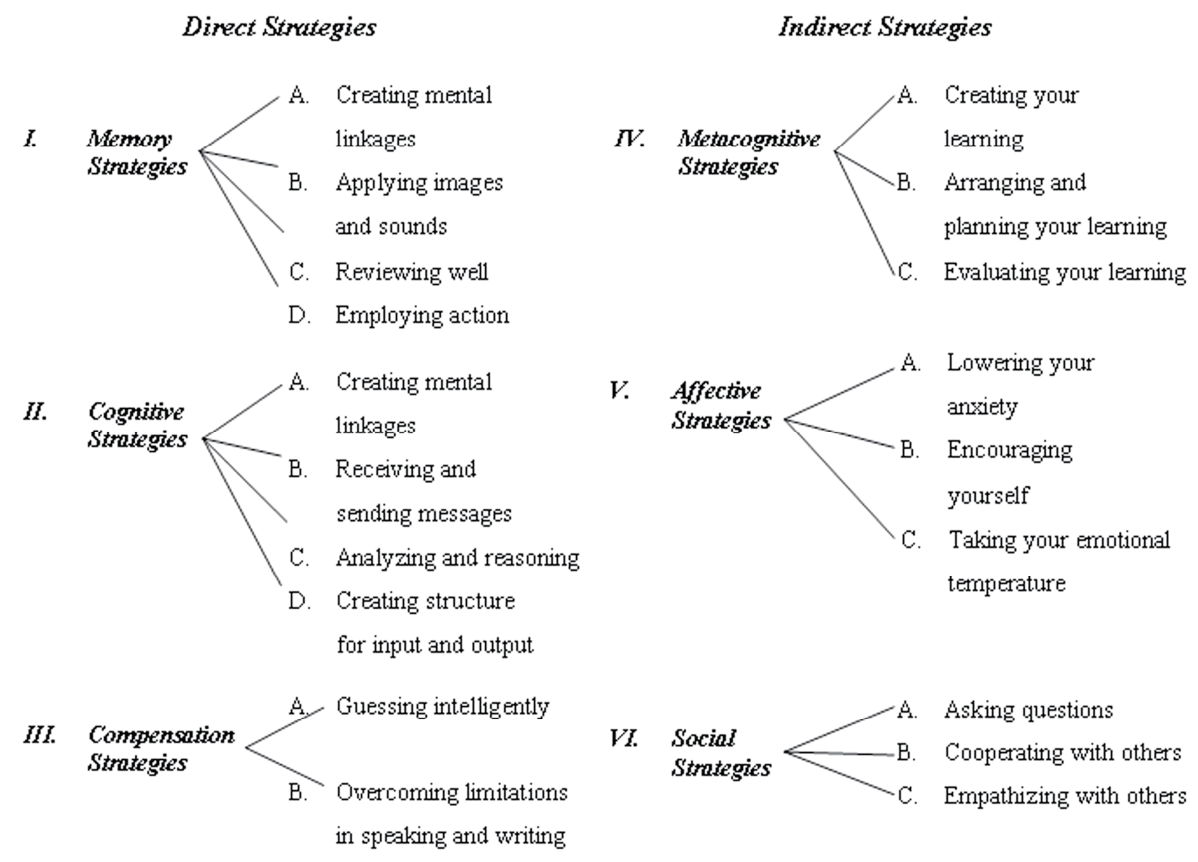

Many studies of second language acquisition and learning (e.g., LarsenFreeman and Long 1991, O'Malley and Chamot 1990, Oxford 1990) agree that language learning strategy use is one of the most important factors in second language acquisition. A large number of studies in second language learning (e.g. Green and Oxford 1995, Griffiths and Parr 2001, Oxford 1990, Park 1997, Wharton 2000) point out that successful learners seem to use a wider variety of language learning strategies than unsuccessful learners. For example, as shown by Green and Oxford (1995), successful students often use more active and naturalistic strategies, and use more combinations of strategies than less successful students. Meanwhile, a number of studies also report on the relationships between learning strategies and a student's performance; for instance,

according to Oxford (1990), it is believed that language learning strategies are one of several individual factors that could lead learners to the goal of learning a language. Several studies (e.g. Bruen 2001, Cohen 1998, Oxford 1990, O'Malley and Chamot 1990, Purpura 1997, Shen 2005, Wharton 2000) also reveal that selecting appropriate strategies can enhance learners' second language learning. Therefore, it is clear that the choice of strategies used by second language learners plays a significant role in successful second language learning.

Concerning the English proficiency of Thai and Vietnamese students, the puzzle is "Why are Vietnamese students more proficient in English than Thai students even though teaching and learning English is still very limited in Vietnam?" (Thinh 1999). Given the focus of this paper on 
enhancing the English proficiency of Thai students and the importance of learning strategies, the specific objectives of this study are twofold: 1) to identify Thai and Vietnamese undergraduate students' language learning strategies in learning English, and 2) to compare their language learning strategies.

\section{Procedures}

\subsection{Selection of Academic Institutes}

To insure that the results obtained from the study can be generalized to the target population, we selected as sample institutes the Faculty of Arts at Chulalongkorn University, Bangkok, Thailand, and the Faculty of Linguistics, the Faculty of International Studies, and the Faculty of Oriental Studies at the University of Social Sciences and Humanities, Vietnam National University, Hanoi, Vietnam ${ }^{2}$. The selection was based on their common characteristics. First, both of these universities are considered as among the top five universities of Thailand ${ }^{3}$ and Vietnam, respectively. ${ }^{4}$ Second, both are public universities which have a long historical background in education. Third, before entering the two universities, these students must pass a university entrance examination. Finally, both have faculties offering specialized courses in language and literature. Therefore, it can be seen

\footnotetext{
${ }^{2}$ The Vietnamese university system is different from that of Thailand. That is, the University

of Social Sciences and Humanities is a constituent of the Vietnam National

University, Hanoi, Vietnam.

3 From

$<$ www.cuqa.chula.ac.th/suggest/sug_answer.as

p?>

4 From

$<$ www.rosalux.de/cms/index.php?id=4848>
}

that these two universities are comparable to a considerable extent.

\subsection{Participants}

Two groups of university students were drawn from these two universities. The total number of participants was 136 undergraduates. The Thai participants were 84 Thai EFL students-26 males $(31.0 \%)$, and 58 females $(69.0 \%)$. The Vietnamese participants were 52 undergraduate students-24 males (46.2\%) and 28 females (53.8\%). Details of the participants in this study are summarized in Table 1. 
Table 1: Summarized Details of the Participants

\begin{tabular}{|c|c|c|c|c|c|}
\hline Participants & Institution & Faculty & Age & $\begin{array}{c}\text { Level of } \\
\text { Study }\end{array}$ & Gender \\
\hline \multirow[t]{2}{*}{$\begin{array}{c}\text { Thai } \\
\text { University } \\
\text { Students }\end{array}$} & $\begin{array}{l}\text { Chulalongkorn } \\
\text { University, } \\
\text { Thailand }\end{array}$ & Arts & $17-21$ & $\begin{array}{c}\text { First and } \\
\text { Second -year }\end{array}$ & Male $=26(31.0 \%)$ \\
\hline & & & $\mathrm{M}=19.0$ & & $\begin{array}{c}\text { Female }=58(69.0 \%) \\
\mathrm{N}=84\end{array}$ \\
\hline \multirow[t]{2}{*}{$\begin{array}{c}\text { Vietnam } \\
\text { University } \\
\text { Students }\end{array}$} & $\begin{array}{c}\text { The University of } \\
\text { Social Science } \\
\text { and Humanities, } \\
\text { Vietnam }\end{array}$ & $\begin{array}{l}\text { Linguistics, } \\
\text { International } \\
\text { Studies, and } \\
\text { Oriental } \\
\text { Studies }\end{array}$ & $17-21$ & $\begin{array}{c}\text { First and } \\
\text { Second -year }\end{array}$ & Male $=24(46.2 \%)$ \\
\hline & & & $M=19.6$ & & $\begin{array}{c}\text { Female }=28(53.8 \%) \\
N=52\end{array}$ \\
\hline
\end{tabular}

\subsection{Data Collection}

Data were collected at Chulalongkorn University, Bangkok, Thailand, and at the University of Social Sciences and Humanities, Vietnam National University, Hanoi, Vietnam. The steps in data collection were as follows:

1) The researchers explained to the department heads and classroom teachers in Thailand and in Vietnam the purposes and procedures involved in order to ask for permission and cooperation for data collection.

2) The Strategy Inventory for Language Learning (SILL) was, then, distributed to Thai and Vietnamese undergraduates. The researchers explained the purpose and procedures of the study. The students were allowed to complete the questionnaire at their own convenience within 40 minutes. In addition, it was emphasized there were no right or wrong responses, and the findings would be kept confidential and used for this study only. The students were also informed that their answers would be useful and beneficial to both Thai and Vietnamese undergraduate students learning English; therefore, honest responses would be appreciated.

3) After the questionnaires were collected, the researchers selected the participants who would participate in the interviews based on the data elicited from the questionnaires. 
4) Interviews were conducted with 8 selected participants ${ }^{5}$ to elicit information about language learning strategies from the SILL. Each semi-structured interview took approximately 10 to 15 minutes. To prevent possible misunderstandings that could be caused by language barriers, the interviews at Chulalongkorn University were conducted in Thai, the native language of both the researchers and the Thai participants. The interviews with Vietnamese students were conducted in Vietnamese, with the help of a research assistant who was fluent in Vietnamese. Once again, the informants were told that the conversation would be kept confidential and used for research only. With the permission of the informants, the interviews were audio-taped, transcribed, and analyzed qualitatively.

\subsection{Data Analysis}

Data analysis was carried out as follows:

1) To identify the language learning strategies of Thai and Vietnamese undergraduate students, the data from the returned questionnaires of each student group which met selection criteria were analyzed based on the six learning strategy

\footnotetext{
5 In order to prove whether these groups of students employed different learning strategies, the interviewees at each site participating in this study were purposely selected according to their motivation level. For the Thai case, five students were chosen to represent highlymotivated learners, and three to represent poorly-motivated ones. As for the Vietnamese case, six students were chosen to represent highly-motivated learners, and two to represent poorly-motivated ones. The criteria used to measure their degree of learning motivation were derived from the background questionnaire which was systematically adapted for the purpose of this study.
}

types classified by Oxford (1990), using descriptive statistics: means, frequency of score, and standard deviation. Statistical analyses were performed using the SPSS program.

2) To compare Thai and Vietnamese undergraduate students' language learning strategies, the data from no.1 were compared in terms of similarities and differences in using language learning strategies.

3) To get more in-depth information about language learning strategies, the interview responses were analysed qualitatively.

\section{Results}

The following sections describe and discuss the results of the comparison of the use of the six categories in the following order: Memory, Cognitive, Compensation, Metacognitive, Affective, and Social categories. To facilitate the comparison of the use of language learning strategies among these students, the findings from the Thai and Vietnamese students are presented concurrently.

\subsection{Memory strategies}

For both Thai and Vietnamese students, this category was ranked sixth. Moreover, both groups agreed that of all the strategies listed in the SILL under this category, visualizing the spelling of a new English word was the most frequently used. However, both groups differed in their opinions regarding the least frequently used strategy. That is, the Thai students infrequently used flashcards to remember new English words, whereas the Vietnamese students tended to act out new English words least. The interviews conducted with the Thai students 
confirmed that Thai students tended to rely on memorizing the meanings of words and using synonyms when learning English, whereas the Vietnamese students preferred to write new English words down in their notebook.

With respect to the use of strategies in the Memory category, Thai students looked for the best way to use memorization as a strategy to help improve the effectiveness of studying English. In this regard, strategies such as using rhymes, synonyms and words in sentences used by Thai students confirm Hong-Nam and Leavell's findings (2006), which revealed that Asian students need memory strategies to help expand their lexical and language structure repertoire. The results of the present study may be influenced by most classroom instruction in Thailand, which is primarily based on audio-lingual and grammartranslation methods even though the communicative approach is promoted (Wongsothorn 2000). The findings also confirm Duong and Nguyen's (2003:14) conclusions for EFL learners in New Zealand, pointing out that "memorization is considered part and parcel of students' learning habits. Therefore, teachers and students have to face the fact that memorization will not be eliminated and should not be denied either."

On the other hand, the data from the interviews with the Vietnamese informants show their preference for writing down new English words in their notebook. This is inconsistent with Wharton (2000) and Yang (1999) who revealed that Asian students expressed a strong preference for Memory strategies rather than other strategies, such as working with others, asking for help, and cooperating with peers. It is possible that the instructional systems typically employed in Vietnam are not frequently didactic and do not emphasize rote memorization (Brogan and Thai Ha 1999) since English teachers attempt to push communicative teaching approaches to the study of English in Vietnam. However, Wharton and Yang's conclusion may be too generalized, stating that Asian students preferred the Memory category over other strategy categories, because both Thai and Vietnamese students reported using this category least among the six categories of language learning strategies.

One explanation for Vietnamese students' preference for writing down new English words in their notebook was suggested by one informant in the interviews. According to the informant, an instructional approach or practice provided by teachers in schools probably shaped how Vietnamese students generally learn English. That is, the teachers make their students write down new words learned from books along with the phonetic symbols corresponding to those words at the same time. This is the way every Vietnamese student is trained in school. In contrast, in Thai schools, most English books and materials used in schools provide phonetic symbols. Thai students need not write them by themselves and have less need to copy new words down in their notebooks. This claim emphasizes one of the differences in the instructional approaches between the two groups of students.

Thai and Vietnamese students differ in terms of the least frequently used strategy. The use of flashcards may appear to be a novelty of Western culture for many Thais. That is, most Thais did not know or use this strategy in memorizing or learning new English words in the past. Only recently has there been an emergence of 
this strategy in international and bilingual schools. Therefore, a majority of Thai students learning English in government schools may not be acquainted with using flashcards in memorizing vocabulary. Vietnamese students, however, used flashcards to help them memorize new English words. One explanation for this finding is that they may be more westernized than Thai students due to the influence of Russian and French colonization, which exerted a strong influence on Vietnamese culture. Using flashcards to aid Vietnamese students in memorizing new English words, therefore, is quite common in learning English in Vietnam.

Moreover, for Vietnamese students, it was found that acting out new English words physically was the least used strategy. It is possible that these students would first use other strategies, such as using synonyms, or inventing new words in memorizing the new English words. Acting out physically the new English words may be another strategy choice to be used when they get stuck in explaining some words in a conversation.

\subsection{Cognitive strategies}

With regard to the reported use of the Cognitive category, Thai and Vietnamese students were different. First, this category was ranked second for Thai students, whilst it was fifth for Vietnamese students. The data elicited by using the SILL showed that the two groups of students shared similar opinions concerning the most popularly used learning strategy. That is, they preferred to use reference materials such as glossaries and dictionaries to help them with English. In contrast, regarding the least frequently used strategy, attending events in which English is spoken was used least by Thai students, whereas using idioms or other routine words was used least by Vietnamese students. Finally, when we asked these students whether they thought and summarized in English when taking notes, the answers to the question indicated that most Thai informants did not frequently take notes in English, whereas most of the Vietnamese informants stated that they regularly took notes in English.

As reflected by the responses from the interviews, the two groups of students differ in the language used in taking notes. That is, Thai students do not take notes in English, while Vietnamese students do when learning English. One plausible explanation is that since English is often taught in Thai to students in primary school, Thai students may be more acquainted with taking notes in Thai rather than in English. That is, they can follow English lessons in class in written Thai better than in English. Conversely, Vietnamese students are pushed to be exposed to English in a classroom setting as much as possible according to the communicative teaching method used for instruction. Thus, they may be more adept at taking notes in English than in Vietnamese. Moreover, again it should be noted that colonization and a familiarity with foreign languages may have a profound influence on Vietnamese students' thoughts and attitudes towards the use of foreign languages. Probably, this explanation is reflected in Vietnamese students' practice of taking notes in English when learning English.

The analysis shows a similarity in terms of the most frequently used strategy by the two groups of students, indicating a strong preference for using bilingual dictionaries. 
This finding is consistent with Arani's (2005) study which reveals that such was the most preferred strategy for medical students. One explanation may be that, in general, a dictionary is a primary source or tool necessary for learning a language, especially learning English as a second language or foreign language in a country where English is not used as an official language or in everyday life. Hence, using a bilingual dictionary is considered more practical than using a monolingual dictionary as users can make comparisons between the words to be used and those in their mother tongue. Moreover, we have observed that most Thai and Vietnamese language students have a dictionary or an electronic dictionary with them when learning English. In addition, using dictionaries may be the quickest way they can find the meanings of words, the parts of speech of words, or learn related words. Thus, it is not surprising that both Thai and Vietnamese students studying English as a foreign language rely on bilingual dictionaries when learning English.

The fact that Thai students rarely attend events in which English is spoken may be explained by the status of English as a foreign language. That is, the use of English remains minimal in day-to-day communication or outside the classroom. Besides, the medium of instruction mostly used in regular English classes is Thai, the learners' mother tongue. These reasons may account for the lack of opportunity for Thai students to use or interact in English outside the classroom or attend events in which English is primarily used as a means of communication. Moreover, it may be said that a majority of Thai students are shy to speak English with other people. According to Pornpibul (2005), Thai students lack the skills to communicate competently, and they are reluctant to speak English with their friends or other people. Therefore, Thai students may not be interested in attending an event in which English is spoken.

Vietnamese students infrequently used idioms or other routine words. According to Canh (1999), although the communicative approach is pushed in learning English in Vietnam, students rarely have opportunities for English communication outside the classroom. What they learn inside the classroom is for future use, rather than for immediate use. Therefore, in this context, it is critical to maintain a good balance between instruction, correction, and communication. In this case, it may be said that the difficulty in creating realistic English situations for Vietnamese students who have no real-life communication in English may lead to the infrequent use of idioms or routine words.

\subsection{Compensation strategies}

The data measured by the SILL reveal that the two groups of students shared the same opinion towards the most dominant strategies under the Compensation category. That is, they would guess the meaning of unfamiliar words, and use circumlocutions or synonyms mostly. However, the analysis of the data obtained from the SILL also reveal that Thai students rarely changed to a topic for which they know words, while Vietnamese students hardly anticipated what a person might say. In addition, the interviews with the Thai informants also confirmed the frequent use of guessing meaning from context and using circumlocutions in conversation. Meanwhile, the Vietnamese informants reported that asking interlocutors for help with the meaning of unfamiliar words was the strategy that they preferred to use the most. 
Given the order and ranking of the Compensation category used by Thai and Vietnamese students, the results of this study are consistent with several other studies focusing on the language learning strategies of EFL learners. For example, Yu's (2003) and Kaotsombut and Suwattananand's (2004) studies indicated that the Compensation category was reported being used the most frequently by Thais, while the Memory category was reported as being the least frequently used. According to Oxford (1990), not only beginners but also advanced learners and even native speakers use Compensation strategies to help them overcome difficulties when speaking and writing. Furthermore, all students, when learning English in class, are expected to use the language as a medium in learning and mastering English. Thus, when they are unable to communicate, they will try to use various Compensation strategies in order to reach their goals and objectives. Therefore, based on consistency of the findings, it might be said that the Compensation category is the sole learning category in the repertoire of learning strategies of every EFL student.

The study showed that the two groups of students tended to guess the meaning of new words from context and employed circumlocution. These findings are consistent with Srinarawat and Jitbunjong (2001), who determined the connection between learning strategies and the participants' levels of achievement. Their study found that Thai undergraduate students from two levels of achievement, a high achievement group and a low achievement group, made similar use of guessing the meaning of new words during a conversation, circumlocution, and trying out new words though uncertain about whether they could use them.
Furthermore, it was found that changing to a topic for which they know words was used least. One explanation for this is that Thai students may not prefer to talk about a situation or topic they do not know well or know almost nothing about because they are shy or feel embarrassed when they make mistakes. As a result, they may choose or engage in a topic or event they are involved in or know well.

The data elicited from the interviews with the Vietnamese informants highlight the importance of asking their interlocutors for help. According to Brown (2000), a strategy commonly found among second language learners is a direct appeal for help. For instance, they may ask a native speaker or the teacher when they do not know the exact word they want to use. Alternatively, they may try to guess the target word and then ask the interlocutor if it is correct. Consistent with Brown's suggestion, the current study reveals that Vietnamese students turn to ask the interlocutor for help most often when they have communication problems. Therefore, it seems that Brown's claim can explain the findings of the present study in the sense that such a compensation strategy as asking the interlocutor or their peers for help contributes to Vietnamese students' proficiency in learning English.

\subsection{Metacognitive strategies}

There is a consensus on the reported use of the Metacognitive category by Thai and Vietnamese students. That is, this category was ranked third among the six categories of language learning strategies used by both Thai and Vietnamese students. However, looking at the strategies under this category, Thai students tended to learn from their mistakes most, while Vietnamese students 
paid attention when someone was speaking most. Furthermore, Thai and Vietnamese students reported different least preferred strategies. Thai students rarely planned daily or weekly learning objectives, while for Vietnamese, students finding people to talk to in English was the strategy used least. Finally, the responses from the interviews showed agreement in that most of the informants from the two groups of students completed assignments and readings before attending English classes.

The ranking of the Metacognitive category reported by both groups is consistent with Mullins (1992) on successful English language learning strategies used by Thai university students. Her study reveals that, of all the six categories, the Metacognitive category was ranked third. This finding is also partly confirmed by Oxford's (1990) study, which illustrates that the Metacognitive category, related to general problem-solving strategies during the planning and monitoring learning processes, is quite frequently employed by EFL learners.

Thais' preference for learning from their mistakes in using English may be explained by the fact that learning autonomy and life-long learning are promoted as a goal of Thai education. Therefore, in general, Thai students should learn or practice by themselves before asking classroom teachers or other people for help. In this case, learning from their mistakes is appropriate in English language learning because the students may realize what they have incorrectly done and will not do it over again. Besides, Thai students participating in this study may be familiar with the approach whereby teachers ask students to correct their mistakes before providing them with the answer key. These reasons can support such learning behaviour, showing that Thai students prefer to learn from their mistakes.

Meanwhile, Vietnamese students preferred to pay attention when someone made a statement or lectured. This finding is probably explained by the assumption that a majority of Vietnamese students may be curious to learn new things from other people. Also, these students are studying in the field of language and literature; therefore, in general they should understand the concepts of both the language and culture of the target language. As a result, to avoid misunderstandings in conversation, these students may try to listen very carefully to what speakers are talking about. Moreover, in a manner of speaking, it is appropriate that interlocutors should pay attention to what the speaker is saying. Giving attention to what they say, thus, may be one of the useful strategies for them, which shows the intention of the listeners and can help their English learning.

However, that Thai students rarely plan what to accomplish in learning English each day or each week may be explained by the fact that since Thai students have to learn a lot of subjects each semester (about 6 to 8 subjects), they will undoubtedly have to do a number of assignments and exercises after class, including external reading for the next class. Therefore, they may not have much time to plan or set goals for what to accomplish in learning English each week.

Another point to consider is that both Thai and Vietnamese students rarely found people to talk to in English. One possible explanation is that, for Vietnamese 
students, as claimed by Canh (1999), when they fail to understand something, they do not dare to ask for clarification in public for fear of losing face. In the classroom, they are not pro-active enough to initiate interaction either. These behaviours are influenced by Confucianism, like in Thai society. Furthermore, similar to Thai students, particularly in the past, Vietnamese students are expected to sit quietly unless the teacher calls on them individually to speak in class. When a particular student is called upon to speak, his or her response tends to be very brief in the form of either a phrase or a short sentence. This 'may' be the explanation why Thai and Vietnamese students are not interested in finding people, especially native speakers to talk to in English.

Moreover, for Thais, finding people to talk to in English is a rarely used strategy. Probably, they lack confidence to speak English with their peers or counterparts as Thai is the dominant language in Thai society. Normally, they speak Thai, their mother tongue, with their friends in their everyday life. Therefore, this may lead to a lack of opportunity for Thai students to practice English speaking skills, explaining the poor speaking skills of many Thai students.

\subsection{Affective strategies}

The findings show certain differences in using the Affective category by Thai and Vietnamese students. This category was ranked fifth for Thai students, and fourth for Vietnamese students. Furthermore, of all the affective strategies listed in this category, trying to relax when anxious about using English was the most frequently used strategy for Thai students, whereas encouraging themselves to continue to try harder and do their best in learning English was most frequently used by Vietnamese students. However, with regard to the least used strategy by the two groups of students, the data elicited by the SILL revealed that they did not record their feelings about learning English in diaries. The data from the interviews confirmed that sleeping was the strategy that Thai students used most to relieve stress from learning English, while Vietnamese students preferred listening to music and going out with their friends.

The findings indicated that trying to relax when anxious about learning English is a common strategy for language students. For Thai students, this strategy was reflected by both the data elicited by the SILL and the interviews. For Vietnamese students, trying to relax when anxious about learning English was also reflected by both the data measured by the SILL and from the interviews, indicating that going out, riding a motorbike, or listening to music are the strategies employed to relieve from learning English.

Given the fact that Vietnamese students preferred encouraging themselves to try harder and do their best, it is possible that the Vietnamese students in this study are quite hard-working, disciplined and diligent. Besides, historically, the fact that Vietnam was colonized by Russia and France for a long time drove the Vietnamese people to be determined, patient, and disciplined in order to achieve independence. Moreover, according to Tuy (1999), cited in Canh (1999), in Vietnam, education is imperative because Vietnamese people view English as a tool for more attractive and lucrative employment opportunities. In addition, students who fail exams are viewed as academically incompetent. Therefore, encouraging them to keep trying harder 
and do their best, influenced by historical events and their inspiration, is the strategy that they preferred to use most frequently when learning English.

Moreover, for both Thai and Vietnamese students, it is interesting to find the low use of recording their feelings about learning English in diaries. A possible explanation for this may be that writing diaries or journals is not an Asian habit. That is, the two groups of students never think of writing a diary as this is chiefly a Western practice. Instead, these students might choose to express their feelings about learning English to their friends, parents or teachers whom they regard as reliable figures if they have a problem about learning English, as reflected by the responses from the interviews.

\subsection{Social strategies}

With respect to the order and ranking of the Social category, for Thai students, this category ranked fourth, while it was second for Vietnamese students. Furthermore, the two groups of students were different in the most frequently used strategy. That is, Thai students preferred to ask speakers to slow down, repeat, or clarify what was said, while Vietnamese students expressed a preference for asking people to correct their pronunciation. However, the data elicited by the SILL showed a similarity with regard to the least used strategy. That is, both groups of students rarely have a regular English learning partner. Moreover, the interview data revealed that most of the informants were interested in speaking English with native speakers, and asking native speakers to correct their pronunciation.

Given the ranking of the Social category, the finding is partly in line with Phillips'
(1991) study of Asian ESL students enrolled in college IEPs (a language learning institute for pre-admissions university ESL students). The study reveals that Asian ESL students used the Social category more than Affective and Memory categories.

In the present study, it is interesting to find that the Social category was the second strategy most preferred by Vietnamese students. As suggested by Oxford (1990), cooperation is an imperative element in students' learning because it can "encourage positive independence and mutual support" (146) and show a host of positive effects such as higher self-esteem, increased confidence and enjoyment, greater and more rapid achievement, etc. In this case, the use of the Social category by Vietnamese students might have been influenced by their classroom instruction providing a wide variety of activities encouraging students to work with others, or motivating them to use English in class with their counterparts. This may be one of the reasons partly accounting for the high English proficiency of Vietnamese students and their use of the Social category.

More interestingly, for Thai students, the Social category was ranked fourth among the six categories of language learning strategies. This is strange because the current English curriculum in Thailand places an emphasis on life-long education for self and social improvement through promoting communicative competence (Wongsothorn 2000). Thai students are expected to use Social strategies more in English learning, especially in a classroom setting. According to Maskhao (2002), one explanation for this unexpected finding may lie with classroom teachers, who may not be adept at new teaching 
methods, promoting learner-centeredness and interaction with peers in class, and providing increased amounts of naturalistic communication.

Referring to use of the strategy of having a regular English learning partner, the interesting point lies in its ranking as the least favorite strategy used by the two groups of students. As suggested by Oxford (1990), this strategy can enhance and promote learning a second or foreign language, particularly in the language classroom. In this case, as previously mentioned, Thai students are too shy to speak English either with Thais or native speakers. Moreover, most Thai teachers still use a textbook-based, grammartranslation approach whose lessons mostly focus on grammatical structures, vocabulary, and reading. Therefore, in regular English classrooms, Thai students might not have a chance to practice social interaction with their counterparts. For Vietnamese students, it might be true that they are familiar with practicing by themselves at home by using electronic tools (e.g., CD-ROMs and voice recorders) to improve their English performance. This is substantiated by the responses from the interviews with Vietnamese students, showing that most of the informants rely on using voice recorders, surfing the Internet to read news, and using CD-ROMs to practice their English skills. As a result, they may prefer to learn by themselves rather than consult with English learning partners.

Moreover, the findings from the interviews confirmed the results of the SILL that, among the social strategies that Thai students reported preferring was to "ask speakers to slow down, repeat, or clarify what was said," while for Vietnamese students, it was "asking people to correct their pronunciation." In this particular contrast, it is clear that Thai students tend to ask their interlocutors to adapt their speech to them, while the Vietnamese students prefer asking their interlocutors to help them improve their speech. It is clear that Thais are too easily embarrassed to make mistakes and let others correct them. On the other hand, Vietnamese students are not afraid to make mistakes, but learn from them and dare to ask their interlocutors to correct their pronunciation. This is one of several ways to learn a language like native speakers. This strategy adopted by the Vietnamese students may be due to their being westernized since Vietnam has been influenced by the legacy of colonization and foreign domination.

All the results of the comparison of Thai and Vietnamese university students' language learning strategies are summarized in Table 2. 
Table 2: Comparison of Strategies Used by Thai and Vietnamese Students

\begin{tabular}{|c|c|c|c|}
\hline Category & Features & Thai Students & Vietnamese Students \\
\hline \multirow{4}{*}{ Memory } & Ranking & Sixth $(\mathrm{M}=2.75, \mathrm{SD}=0.54)$ & Sixth $(\mathrm{M}=3.07, \mathrm{SD}=0.52)$ \\
\hline & $\begin{array}{l}\text { Most frequently used } \\
\text { strategy }\end{array}$ & \multicolumn{2}{|c|}{ Visualizing the spelling of a new English word } \\
\hline & $\begin{array}{l}\text { Least frequently used } \\
\text { strategy }\end{array}$ & $\begin{array}{l}\text { Using flashcards to remember new English } \\
\text { words }\end{array}$ & Acting out physically new English words \\
\hline & $\begin{array}{l}\text { Data from the } \\
\text { interviews - how to } \\
\text { memorize new English } \\
\text { words }\end{array}$ & $\begin{array}{l}\text { Memorizing the meanings of words, using } \\
\text { synonyms }\end{array}$ & $\begin{array}{l}\text { Writing new English words down in their } \\
\text { notebook and reading them repeatedly }\end{array}$ \\
\hline \multirow{4}{*}{ Cognitive } & Ranking & Second $(\mathrm{M}=3.07, \mathrm{SD}=0.54)$ & Fifth $(\mathrm{M}=3.29, \mathrm{SD}=0.58)$ \\
\hline & $\begin{array}{l}\text { Most frequently used } \\
\text { strategy }\end{array}$ & \multicolumn{2}{|c|}{ Using glossaries or dictionaries for help } \\
\hline & $\begin{array}{l}\text { Least frequently used } \\
\text { strategy }\end{array}$ & \multicolumn{2}{|c|}{ Attending events in which English is spoken Using idioms or other routines } \\
\hline & $\begin{array}{l}\text { Data from the } \\
\text { interviews - how to take } \\
\text { notes }\end{array}$ & \multicolumn{2}{|c|}{ Taking notes } \\
\hline \multirow{4}{*}{ Compensation } & Ranking & First $(\mathrm{M}=3.67, \mathrm{SD}=0.55)$ & First $(\mathrm{M}=3.59, \mathrm{SD}=0.55)$ \\
\hline & $\begin{array}{l}\text { Most frequently used } \\
\text { strategies }\end{array}$ & \multicolumn{2}{|c|}{ Guessing meanings of unfamiliar words } \\
\hline & $\begin{array}{l}\text { Least frequently used } \\
\text { strategy }\end{array}$ & $\begin{array}{l}\text { Changing to a topic for which they know } \\
\text { words }\end{array}$ & Anticipating what a person will say \\
\hline & $\begin{array}{l}\text { Data from the } \\
\text { interviews - how to } \\
\text { guess the meaning of } \\
\text { unfamiliar words }\end{array}$ & $\begin{array}{l}\text { Guessing meanings from context or using } \\
\text { circumlocutions freqently }\end{array}$ & $\begin{array}{l}\text { Asking their interlocutors or other } \\
\text { persons for help }\end{array}$ \\
\hline \multirow{4}{*}{ Metacognitive } & Ranking & Third $(\mathrm{M}=3.24, \mathrm{SD}=0.68)$ & Third $(\mathrm{M}=3.50, \mathrm{SD}=0.56)$ \\
\hline & $\begin{array}{l}\text { Most frequently used } \\
\text { strategies }\end{array}$ & Learning from own mistakes & $\begin{array}{l}\text { Paying attention when someone is } \\
\text { speaking }\end{array}$ \\
\hline & $\begin{array}{l}\text { Least frequently used } \\
\text { strategy }\end{array}$ & Planning objectives in learning each week & Finding people to talk to in English \\
\hline & $\begin{array}{l}\text { Data from the } \\
\text { interviews - how to } \\
\text { prepare yourself before } \\
\text { class }\end{array}$ & \multicolumn{2}{|c|}{ Completing the assignments, homework, and readings } \\
\hline \multirow{4}{*}{ Affective } & Ranking & Fifth $(\mathrm{M}=3.07, \mathrm{SD}=0.70)$ & Fourth $(\mathrm{M}=3.36, \mathrm{SD}=0.64)$ \\
\hline & $\begin{array}{l}\text { Most frequently used } \\
\text { strategy }\end{array}$ & Trying to relax whenever anxious & Encouraging self to try harder \\
\hline & $\begin{array}{l}\text { Least frequently used } \\
\text { strategy }\end{array}$ & \multicolumn{2}{|c|}{ Recording their feelings in learning diaries } \\
\hline & $\begin{array}{l}\text { Data from the } \\
\text { interviews - how to relax }\end{array}$ & Sleeping & $\begin{array}{l}\text { Listening to music and going out with } \\
\text { friends }\end{array}$ \\
\hline \multirow{4}{*}{ Social } & Ranking & Fourth $(\mathrm{M}=3.21$, and $\mathrm{SD}=0.69)$ & Second $(\mathrm{M}=3.54$, and $\mathrm{SD}=0.62)$ \\
\hline & $\begin{array}{l}\text { Most frequently used } \\
\text { strategy }\end{array}$ & $\begin{array}{l}\text { Asking speakers to slow down, repeat, or } \\
\text { clarify what was said }\end{array}$ & $\begin{array}{l}\text { Asking other people to correct } \\
\text { pronunciation }\end{array}$ \\
\hline & $\begin{array}{l}\text { Least frequently used } \\
\text { strategy }\end{array}$ & \multicolumn{2}{|c|}{ Having a regular English learning partner } \\
\hline & $\begin{array}{l}\text { Data from the } \\
\text { interviews - how to } \\
\text { correct pronunciation }\end{array}$ & \multicolumn{2}{|c|}{$\begin{array}{c}\text { Speaking English with native speakers, and asking native speakers to correct their } \\
\text { pronunciation }\end{array}$} \\
\hline
\end{tabular}




\section{Conclusion and discussion}

The purpose of the present study was to compare language learning strategies used by Thai and Vietnamese undergraduate students. As shown by this study, the Strategy Inventory for Language Learning (SILL) version 5.1 developed by Oxford (1990) and interviews can be successfully used to identify similarities and differences in language learning strategies employed by these two groups of students, particularly when learning English. The results of the analysis show that Thai students used direct strategies in learning English more frequently than indirect strategies. Meanwhile, Vietnamese students, distinctively, used indirect strategies more often than direct strategies. These findings may result from differences in the teaching and learning of English in these two countries. That is, as shown elsewhere, Thailand has a long history of English education. In the past, English teachers employed the grammar translation method and then the audio lingual method in English instruction. These two teaching approaches may be deep-rooted in teaching English in Thailand and still exert an influence today, even though education planners have changed the English curriculum in order to suit international needs, and communicative language teaching has been adopted. Moreover, English teachers probably are not used to such a new method (Maskhao 2002). Therefore, it is possible that Thai students are still familiar with traditional approaches to learning English. As opposed to Thailand, teaching English in Vietnam was mostly promoted after Vietnam adopted its Doi Moi policy in 1986. That is the time when communicative language teaching emerged in language teaching. Therefore, the way Vietnamese students learn English may focus on communicative functions, a way which does not directly involve the structures of the target language.

The analysis also showed that of all the six categories, Vietnamese students used Social and Affective categories more than Thai students. One explanation is that the teaching pedagogy between Thailand and Vietnam may be different. Thai students may learn English and have a chance to use English only in class, while Vietnamese students are probably pushed to learn English by interacting with others in society. Moreover, the Vietnamese are active in learning foreign languages since Vietnam was colonized by numerous Western countries. Speaking English or other foreign languages, therefore, is more common in Vietnam than Thailand.

Likewise, previous studies reveal that successful language students behaved in unique ways when learning a language. For example, Kaotsombut and Suwattananand (2004) and Mullins (1992) state that most Thai high-level English language students frequently guessed the meaning of unfamiliar words, used circumlocutions or synonyms, and used gestures. The present study also discovered that Thai students engaged in the active use of such strategies. Therefore, if such strategies are typically used by successful learners, they can be useful to less successful learners to help them learn a foreign language effectively and become better language learners as claimed in several studies (e.g., Green and Oxford 1995, Oxford 1990, Wharton 2000). Such strategies should be continuously promoted and used as guidelines for helping less successful Thai learners to improve the effectiveness of their English learning. 
Bearing the concept of language ecology in mind, since language is the primary medium through which a society articulates its culture and history, it provides the cognitive structure through which its people comprehend their world (Kachru and Nelson 2001). The language ecology in Thailand and that in Vietnam are very different. This reason may lead to differences in the use of learning strategies among these two groups of students. To illustrate, according to Thinh (2006), the Vietnamese have been influenced by foreign interventions and the subsequent use of a foreign language as the national or official language spread through the country. In particular, in the twentieth century, direct involvement in Vietnam by such powers as China, France, Japan, the Soviet Union and the United States exerted various profound influences on language attitudes, language change, and language choice and use. Consequently, such influence over Vietnam indeed helped not only shape Vietnam's foreign language education policy, but also the Vietnamese's thoughts and worldview about acquiring a language. Simply put, they may be more open and enthusiastic about learning a foreign language when compared with their Thai counterparts. Unlike Vietnam, Thailand has never been colonized by a foreign country. The official language is Standard Thai, which is a national symbol. Moreover, Thailand is a largely monolingual society where Thai is the medium of communication. This reason probably makes it difficult to learn a foreign language. That is, the widespread use of Thai may influence and hinder Thai students from acquiring the target language because of certain aspects such as differences in the language system between the two languages, attitude towards foreign languages, etc.
The results of the present study, particularly the reported use of language learning strategies by Vietnamese students, are congruent with Grainger's (1997) study revealing that students of Asian background preferred Compensation and Social strategy categories. However, the results of the use of the Memory category reported by the two groups of students are not consistent with several studies (e.g., Politzer and McGroarty 1985, Wharton 2000, Yang 1999), revealing that Asian students have stronger preferences for the Memory category than for other communicative strategies such as working with others, asking for help, and cooperating with peers. One explanation for the contradictory findings is that such studies may report the whole picture of learning strategies used by students from several different cultural backgrounds, which may be too generalized. Likewise, it should be noted that the present study investigated only two nationalities: Thai and Vietnamese. Thus, the results cannot lead to a larger claim.

However, it is interesting when the results are compared with other previous studies (e.g., Grainger 1997, Hong-Nam \& Leavell 2006, Yang 1999, Wharton 2000) conducted with students of European and English-speaking country background, as it can be seen that most of the studies agree that the Social, Compensation, and the Metacognitive categories are the strategies that these students prefer most among the six categories of language learning strategies. In other words, Social and Metacognitive categories are grouped as indirect strategies according to Oxford (1990). Therefore, it may be said that, when Thai and Vietnamese students are compared, the Vietnamese students are quite similar to students of European and English-speaking country backgrounds in 
terms of the higher use of indirect strategies, while the Thai students mostly prefer to use direct strategies. Again, this may be the result of the colonization of Vietnam by both Western countries, leading to the difference in language ecology between the two nations.

Using the SILL to elicit learning strategies can provide insight into the use of language learning strategies of these two groups of students. However, the results of the present study are not claimed to be exhaustive, with the caveat that the SILL does not tap into language attitudes, but in combination with the interviews, some of the explanations offered for the differences were attributed, at least indirectly, to different attitudes toward foreign languages and their learning. This should be taken into account when the results of this study are interpreted. Thus, in order to substantiate and verify the findings of this study, further investigation should include a deeper analysis of the differences in each of the strategies. Further studies should combine various qualitative approaches such as think-aloud protocols, written diaries, longitudinal study, and other methods which might provide and support the actual use of strategies and more sample-specific data.

\section{Pedagogical Implications}

This study is pedagogically beneficial in language teaching in a number of ways. First, the results indicated that both Thai and Vietnamese students used different language learning strategies. Therefore, a practical implication is that students should know how to use a variety of language learning strategies effectively, as well as understand how to use language learning strategies flexibly. According to Fedderholdt (1998), in language learning, it is indispensable for learners to reflect on their own learning process, and habitually estimate whether the use of language learning strategies is effective for improving their language proficiency. Meanwhile, Chamot (1999) suggests that language teachers should concentrate on integrating language learning strategies in class and explain the effectiveness of each strategy. This is because awareness of language learning strategies can empower students to become proficient in English. Therefore, teaching English should include strategies in using English effectively. Students should not be forced to follow only one strategy. A combination of language learning strategies is imperative.

In addition, classroom teachers, in turn, should become more aware of the learning strategies that their students are (and are not) using so that they can develop teaching methodologies that are compatible with their students' behaviours or ways of learning. According to Ellis (1994), language learning is enhanced when students' language learning strategies match the teaching methodology. In this case, the results of this study identify that both Thai and Vietnamese university students predominantly use the Compensation strategy in learning English. Therefore, in order to facilitate learning, especially in an EFL context where students do not have much chance to be exposed to authentic English, classroom management should be designed to promote using circumlocutions during communication as compensation-type activities are well suited to Thai and Vietnamese students.

Meanwhile, given that the use of Social and Affective categories by Thai students and Vietnamese students is relatively low, compared to other category strategies, one implication is that applying these two learning strategies in the language 
classroom should be treated as a long-term instructional goal. The successful acquisition of speaking competence can be achieved only if language teachers patiently and continuously promote the Social and Affective strategy categories to Thai students.

Likewise, language curricula, materials and instructional approaches should incorporate the strategies used by students to accommodate their learning behaviours. In this regard, Dickinson (1987) states that using appropriate learning strategies can enable students to take responsibility for their own learning by enhancing autonomy, independence and selfdirection. In an EFL context, particularly, learners do not usually have a chance to develop these strategies naturally outside their classes due to the fact that they do not usually have direct contact with native speakers in their environment. Therefore, material developers should include activities that encourage students to take risks and use their available language knowledge without being afraid of making errors.

\section{References}

Angwattanagul, S. 1992. Approaches to Teaching English as a Foreign Language (วิธีการสอนภาษาอังกฤษเป็นภาษาต่างประเทศ).

Bangkok: Chulalongkorn University (in Thai).

Arani, J. A. 2005. Learning Strategies of English Medical Terminologies in the Students of Medicine. $<$ www.espworld.info/Articles_13/DO C/Learning\%20Strategies_JA.doc>

Brogan, M., and Thai Ha, N. 1999. The 3 R's of Teacher Training in Vietnam: Revising, Reviving and Researching. $4^{\text {th }}$ International Conference on Language and Development. $<$ www.languages.ait.ac.th/ hanoi_proceedings/>

Brown, D. 2000. Principles of Language Learning and Teaching. New York: Addison Wesley Longman.

Bruen, J. 2001. Strategies for Success: Profiling the Effective Learner of German. Foreign Language Annals 34 (3): 216-225.

Bunnag, S. 2005. English Skills Lowly Ranked: Tests put Thais near Bottom in S.E. Asia. Bangkok Post (10 August 2005): 5.

Canh, L, V. 1999. Language and Vietnamese Pedagogical Contexts. $4^{\text {th }}$ Iinternational Conference on Language and Development.

$<$ www.languages.ait.ac.th/hanoi_procee dings/>

Chamot, A. 1999. Learning Strategy Instruction in the English Classroom. $<$ http://langue.hyper.chubu.ac.jp/jalt/pub /tlt/99/jun/chamot>

Chulalongkorn University Academic Service Centre. 2000. Report on the project to evaluate the development of education at the primary and secondary levels in government and private sectors- Science, Mathematics and English. Bangkok: CU Academic Service Centre. (For the Budget Bureau).

Cohen, A. 1998. Strategies in Using a Second Language. New York: Longman. 
Dickinson, L. 1987. SelfInstruction in Language Learning. Cambridge, MA: Cambridge University Press.

Duong, T. H. O., and Nguyen, T. H. 2003. Memorization and EFL Students' Strategies at University Level in Vietnam. Teaching English as a Second or Foreign Language 10 (2): $1-21$.

Ellis, R. 1994. Understanding Second Language Acquisition. Oxford: Oxford University Press.

Fedderholdt, K. 1998. Using Diaries to Develop Language Learning Strategies. $<$ http://langue.hyper.chubu.ac.jp/jalt/pub /tlt/98/apr/>

Foley, J. A. 2005. English in Thailand. RELC 36 (2): 223-234.

Grainger, P. R. 1997. Language Learning Strategies for Learners of Japanese: Investigating Ethnicity. Foreign Language Annals 30 (3): 378-385.

Green, J. M., and Oxford, R. 1995. A Closer Look at Learning Strategies, L2 Proficiency and Gender. TESOL Quarterly 29 (2): 261-297.

Griffiths, C., and Parr, J. M. 2001. Language Learning Strategies: Theory and Perception. ELT Journal 53 (3): 247-254.

Hong-Nam, K., and Leavell, A. G. 2006. Language Learning Strategy use of ESL Students in an Intensive English Learning Context. System 34: 399-415.
Kachru, B. B., and Nelson, C. L. 2001. World Englishes. In A. Burns and C. Coffin (Eds.), Analysing English in a Global Context: a Aeader: Routledge: 9-25.

Kotsombut, N., and Suwattananand, N. 2004. Language Learning Strategies of Graduate Science Students in EFL Contexts. SLLT 13: 23-40.

Larsen-Freeman, D., and Long. M. H. 1991. An Introduction to Second Language Acquisition Research. London and New York: Longman.

Maskhao, P. 2002. A Case Study of English as a Foreign Language (EFL) Acquisition in a Postgraduate Diploma Course. Doctoral Dissertation, University of Queensland, St. Lucia, Qld.

Mullins, P. 1992. Successful English Language Learning Strategies of Students Enrolled in the Faculty of Arts, Chulalongkorn University, Bangkok, Thailand. Doctoral Dissertation, United States International University, San Diego, CA.

O’Malley, J. M., and Chamot, A. U. 1990. Learning Strategies in Second Language Acquisition. Cambridge: Cambridge University Press.

Office of strategy management. Chulalongkorn University. University Ranking: a Mirror Reflecting Educational Quality. $<$ www.cuqa.chula.ac.th/suggest/sug answer.asp?GID=1362> 
Oxford, R. L. 1990. Language Learning Strategies: What Every Teacher Should Know. New York: Newbury House.

Park Gi-Pyo. 1997. Language Learning Strategies and English Proficiency in Korean University students. Foreign Language Annals 30 (2): 211-221.

Phillips, V. 1991. A Look at Learner Strategy Use and ESL Proficiency. CATESOL: 57-67.

Politzer, R., and McGroarty, M. 1985. An Exploratory Study of Learning Behaviours and their Relationship to Gains in Linguistic and Communicative Competence. TESOL Quarterly 19: 103-123.

Pornpibul, N. 2005. Quantitative and Qualitative Views of EFL Learners' Strategies: A Focus on Communication Strategies. Journal of English Studies 2: 64-87.

Prapphal, K., \& Opanon-amata, 2002. An Investigation of English Proficiency of Thai Graduates. Research Report.

Chulavijai 21 (3): 12-16.

Purpura, J. 1997. An Analysis of the Relationship of Test-takers' Cognitive and Metacognitive Strategy Use and Second Language Test Performance. Language Learning 47 (2): 289-325.

Shen, H. H. 2005. An Investigation of Chinese-character Learning Strategies among Non-native Speakers of Chinese. System 33: 49-68.
Srinarawat, D., and Jittbunjong, R. 2001. A Study of Learning Strategies and Learning Problems of University Students (การศึกษากลวิธีการเรียนและปัญหาการเรียน ภาษาอังกฤษของนักศึกษาระดับมหาวิทยาลัย).

Bangkok: Thammasat University (in Thai).

Thinh, T. H. 1999. Foreign Language Education Policy in Vietnam: the Emergence of English and its Impact on Higher Education. $4^{\text {th }}$ International Conference on Language and Development. $<$ www.languages.ait.ac.th/ hanoi_proceedings/>

Thinh, T. H. 2006. The Role of English in Vietnams' Foreign Language Policy: A Brief History. $<$ http://www.englishaustralia.com.a u/ea_conference2006/proceedings/pdf/

Vietnam National University. 2006. $<w w w \cdot$ rosalux.de/cms/index.php?id=4 848.>

Wharton, G. 2000. Language Learning Strategy Use of Bilingual Foreign Language Learners in Singapore. Language Learning 50 (2): 203-243.

Wongsothorn, A. 2000. 'Thailand'. In Ho Wah Kam and R. L. Wong (Eds.). Language Policies and Language Education: The Impact in East Asian Countries in the Next Decade. Singapore: Times Academic Press: 229-341.

Yang, N. D. 1999. The Relationship between EFL Learners' Beliefs and Learning Strategy Use. System 27: 515-535. 
Yu, L., 2003. Learning Strategies and their Relationship to Listening Comprehension- A Report on Non English Majors in a Medical University in China. Teaching English in China 26 (4): 3-11.

Yunibandhu, R. 2004. Problems Faced by Thai Students Making the Transition From the Thai School System to the International School System. Master's Thesis, Chulalongkorn University. 